patients felt secure in the knowledge that one of us could be obtained in an emergency in a relatively short time. Constant supervision by either doctor or nurse in the follow-up period was prophylactic.

In what way can the patient benefit from this procedure? There appear to be two main advantages. First of all, the waiting-time for operation is greatly reduced and the date of operation can be fixed when he is first seen as an outpatient. Both these factors are of distinct economic and social advantage to the patient, who can plan his life accordingly, instead of waiting for some vague time ahead. Secondly, he can be nursed in familiar surroundings by people he knows, and this has a good psychological effect. Also he does not occupy a hospital bed for several days, and therefore does not have to share communal care. Hospitals hold a real fear for some persons, and early return to familiar surroundings is greatly appreciated.

As regards the general practitioner, he will obviously be involved in more work, and in these days of diminishing medical manpower anything which increases his work-load should be looked at critically. Whether a doctor can cope with this depends largely on his individual commitments and practice arrangements. We personally belong to a group practice of four doctors and find that our arrangements are such that we can easily cope with these cases. In practice the extra work is minimal (involving little more visiting than, say, a case of measles). Anything which increases a general practitioner's clinical responsibility will indirectly make him a better doctor, and we feel that looking after these patients widens our horizon, however slightly.

Altogether we feel that there is a very real place in the National Health Service for this type of procedure, but believe that this depends on trust between surgeon, general practitioner, and patient.

To conclude, we would stress that these cases can be successfully undertaken only if the following criteria are observed: (1) there should be a high standard of co-operation between surgeon, general practitioner, nurse, and patient ; (2) there should be good communication between hospital and general practitioner; (3) the general practitioner should be willing to visit, probably at an inconvenient hour ; (4) the general practitioner should make doubly sure that his deputizing arrangements are adequate and that the patient is aware of them ; and (5) the selection of the type of patient should be primarily the responsibility of the general practitioner, whereas the selection of the type of operation should be the surgeon's responsibility.

\title{
NEW TECHNIQUES
}

\section{Haemagglutination-inhibition Tests for Rubella}

Dr. C. C. Draper and Mr. A. Kelly, Wellcome Research Laboratories, Beckenham, Kent, write: The estimation of serum antibodies is essential in the assessment of exposure to rubella during pregnancy (Banatvala, 1968), and also for the evaluation of candidate vaccines against rubella. The determination of haemagglutination-inhibiting antibodies has been found to be as sensitive as other methods, and has the advantage of speed and comparative simplicity (Field et al., 1967 ; Lennette et al., 1967 ; Stewart et al., 1967). In some instances a feasible method for the use of capillary blood may have advantages over venepuncture, while in other instances a convenient way of storing small quantities of whole venous blood may be of value, especially if there is likely to be delay in the separation of the serum and transmission to the virus laboratory. The successful use of blood collected on absorbent paper has been described for the estimation of antibodies to several viruses (Brody et al. 1964), and the method described here has been found satisfactory for rubella.

\section{METHOD}

Whole capillary or venous blood was collected by two methods. In one method discs of Whatman No. 3 chromatography paper, $21 \mathrm{~mm}$. in diameter, were saturated with blood by applying them to a fingerprick or allowing blood to drop on to them. They were left to dry for an hour on a clean flat surface and were then put into labelled envelopes and stored in a refrigerator at about $-20^{\circ} \mathrm{C}$. One disc was found to absorb about $0.12 \mathrm{ml}$. of blood; this was eluted overnight at $4^{\circ} \mathrm{C}$. in $0.6 \mathrm{ml}$. of isotonic saline, and was then wrung out with fine forceps. About $0.5 \mathrm{ml}$. of fluid so obtained was taken as a $1 / 10$ dilution of serum.

In the other method blood was allowed to drop from finger or syringe on to $11-\mathrm{cm}$. pieces of Whatman No. 3 filter paper, which is very similar to chromatography paper, to form several blots, each a few centimetres in diameter. It was found by experiment that a circle of $6 \mathrm{~mm}$. diameter was equivalent to $0.01 \mathrm{ml}$. of blood, and it was usually possible, with a paper punch, to cut 20 such circles, which were eluted in $1 \mathrm{ml}$. of isotonic saline to give a $1 / 10$ dilution of serum. If fewer circles only could be cut they were eluted in a suitably smaller volume. Wringing out of the circles was easily done by squeezing them in a disposable $1-\mathrm{ml}$. syringe. Though it was more difficult to obtain adequate samples from finger-pricks by using the large pieces of filter paper rather than the smaller discs, the former were easier to dry and handle.

For the removal of non-specific inhibitors of haemagglutination a method suggested by Plotkin et al. (1968) similar to one described for reovirus serology (Mann et al., 1967) was found to give clearer preparations than kaolin extraction (Stewart et al., 1967). The disc eluates were heated at $60^{\circ} \mathrm{C}$. for 30 minutes, and then to $1 \mathrm{ml}$. was added 0.05 $\mathrm{ml}$. of $1 \mathrm{M}$ manganous chloride and 0.05 $\mathrm{ml}$. of a solution of heparin containing 4,000 units per $\mathrm{ml}$. The mixtures were allowed to stand for 20 minutes at $4^{\circ} \mathrm{C}$., when a precipitate was formed, and were then centrifuged at $2,000 \mathrm{~g}$. for 20 minutes. The supernatant fluid was removed and $0.05 \mathrm{ml}$. of $50 \%$ pigeon erythrocytes was added. After standing for 60 minutes at $4^{\circ}$ C. the mixtures were again centrifuged to remove the erythrocytes, the supernatant fluid being taken as the $1 / 10$ dilution of serum.

The haemagglutination-inhibition tests were done by standard methods (Stewart et al., 1967), with twofold dilutions of the serum preparations, made with microtitre apparatus and $0.025-\mathrm{ml}$. volumes, and these were incubated at $35^{\circ} \mathrm{C}$. for 20 minutes with 8 units of haemagglutinin prepared in these laboratories by Tween-ether treatment of rubella virus grown in BHK 21 cell tissue cultures. Instead of day-old chick erythrocytes, however, $0.19 \%$ pigeon erythrocytes was added, the plates being left at $4^{\circ} \mathrm{C}$ for about one and a half hours and then at room temperature for about half an hour for the cells to settle before reading. Because they retained the dark colour of haemolysed blood it was difficult to obtain clear results with the $1 / 10$ serum dilutions from the paper samples, and the lowest dilutions tested were $1 / 20$.

\section{Results}

Through the kindness of Dr. A. H Griffith of these laboratories, venous blood samples were obtained from 55 adults, of a wide range of ages, living in this area. Discs of $21 \mathrm{~mm}$. with capillary blood were also taken from some, while for all a portion of 
the venous blood was put on 21-mm. discs or on the larger pieces of filter paper. All the samples were coded by numbers and were tested for haemagglutination-inhibiting antibodies; sera from the fluid venous blood samples were treated similarly to the eluates. Only $2(4 \%)$ of the subjects were without detectable haemagglutination-inhibiting antibodies (titre $<20$ ) by any of the methods used, a not unlikely result among adults from an urban community.

The Table shows the results of the comparison of serum from fluid venous blood

Comparison of Haemagglutination-inhibiting Antibodies in Blood Collected on Absorbent Paper With Titres in Serum

\begin{tabular}{|c|c|c|c|c|}
\hline \multirow{2}{*}{ Method } & \multirow{2}{*}{$\begin{array}{l}\text { No. of } \\
\text { Comparisons }\end{array}$} & \multicolumn{3}{|c|}{$\begin{array}{l}\text { Titres Obtained as Compared with Parallel } \\
\text { Serum Samples }\end{array}$} \\
\hline & & $\begin{array}{l}\text { Fourfold } \\
\text { Less Than }\end{array}$ & $\begin{array}{l}\text { Not More than } \\
\text { Twofold Different }\end{array}$ & $\begin{array}{l}\text { Fourfold } \\
\text { More Than }\end{array}$ \\
\hline 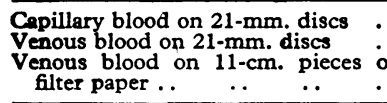 & $\begin{array}{l}28 \\
55 \\
21\end{array}$ & $\begin{array}{l}4(14 \%) \\
2(4 \%)\end{array}$ & $\begin{array}{l}24(86 \%) \\
50(91 \%) \\
21(100 \%)\end{array}$ & $3(5 \%)$ \\
\hline Total ... & 104 & $6(6 \%)$ & $95(91 \%)$ & $3(3 \%)$ \\
\hline
\end{tabular}

a month before elution and testing, but in preliminary trials it was found that antibodies were stable for at least two months when stored at $-20^{\circ} \mathrm{C}$

The conclusion to be formed is that capillary or venous blood collected on absorbent paper can be used for the estimation of serum antibodies to rubella virus in the same way as for other viruses. A disadvantage of this method is that it is difficult to test serum dilutions of less than $1 / 20$ and antibodies may very occasionally occur at a lower titre.

\section{REFERENCBS}

Banatvala, J. E. (1968). Brit. med. F., 1, 561. Brody, J. A., McAlister, R., Haseley, R., and Lee, P. (1964). f. Immunol., 92, 854.

Field, A. M., Vandervelde, E. M., Thompson K. M., and Hutchinson, D. N. (1967). Lancet, 2, 182 . Lennette, E. H., Schmidt, N. J., and Magoffin,
R. L. (1967).

Mann, J. J., Rossen, R. D., Lehrich, J. R., and lotkin, S. A., Bechtel, D. J., and Sedwick, W. D. (1968). Amer. F. Epidem. In press.

Stewart, G. L., Parkman, P. D., Hopps, H. B., Douglas, R. D., Hamilton, J. P., and Meyer,
H. M. (1967). New Engl. f. Med., 276, 554.

\section{Recommendations on Cannabis}

The report on cannabis prepared by the Hallucinogens Subcommittee of the Home Office's Advisory Committee on Drug Dependence (1968, H.M.S.O., 7s. 6d. net) contains a summary of recommendations. These are published below (with the omission of their references to the numbered paragraphs in the report).

(1) We recommend that in the interest of public health it is necessary for the time being to maintain restrictions on the availability of cannabis.

(2) Every encouragement, both academic and financial, should be given to suitable projects for Inquiry into the cannabis problem. Suggestions about areas in which research is required are made.

(3) The law should progressively be recast to give Parliament greater flexibility of control over individual drugs.

(4) The association in legislation of cannabis with heroin and the other opiates is inappropriate and new legislation to deal specially and separately with cannabis and its synthetic derivatives should be introduced as soon as possible.

(5) Unlawful possession of cannabis without knowledge should not be an offence for which the law provides no defence. The practicability of distinguishing between possession intended for use and possession intended for supply should be examined.

(6) Possession of a small amount of cannabis should not normally be regarded as a serious crime to be punished by imprisonment.

(7) The offence of unlawful possession, sale, or supply of cannabis should be punishable on summary conviction with a fine not exceeding $£ 100$, or imprisonment for a term not exceeding four months, or both such fine and imprisonment. On conviction on indictment the penalty should be an unlimited fine, or imprisonment for a term, not exceeding two years or both such fine and imprisonment.

(8) The existing law which inhibits research requiring the smoking of cannabis (section 5 , Dangerous Drugs Act, 1965) should be amended to allow qualified workers to study its use both by observation and by laboratory and social experiments.

(9) Section 5 of the Dangerous Drugs Act 1965 (permitting premises to be used for smoking cannabis, etc.) should be redefined in scope so as to apply only to premises open to the public, to exclude the reference to dealing in cannabis and cannabis resin, and to remove the absolute nature of the liability on managers.
(10) The Advisory Committee should undertake, as a matter of urgency, a review of police powers of arrest and search in relation to drug offences generally with a view to advising the Secretary of State on any changes that may be appropriate in the law, particularly as regards cannabis.

(11) The development of the manufacture of synthetic cannabinols should be kept under review and, if necessary, control should be imposed under powers provided by The Pharmacy and Poisons Act 1933 and The Drugs (Prevention of Misuse) Act 1964.

(12) Preparations of cannabis and its derivatives should continue to be available on prescription for purposes of medical treatment and research. Provision should be made in legislation for records to be maintained so that the position can be kept under review.

Reservations by two members of the subcommittee are recorded in appendices to the report.

The Advisory Committee on Drug Dependence (chairman, Sir Edward Wayne) has sent the report to the Home Secretary, the Secretary of State for Social Services, and the Secretary of State for Scotland.

See leading article at p. 133. 